\title{
Korea's Experience with NPM-Based Reform: Applying the Policy Fashion Concept
}

\author{
Hyeong-Wook Boo*
}

\begin{abstract}
The concept of policy fashion was developed to explain a rapid rise and fall in political support for market-oriented policy reforms in European countries. This study applies the concept to Korea's government reform experience. It offers a conceptual clarification of the concept, explores its usefulness, applies it to Korean government reform, and discusses the theoretical implication of this application.
\end{abstract}

Keywords: policy fashion, New Public Management, good governance

\section{INTRODUCTION}

Harrison (2004) studied three European countries' health policies and found a rapid rise and fall in political support for market-oriented health policy reforms. He proposed the concept of policy fashion as an analytical framework; this powerful concept promises to provide a meaningful explanation for Korea's experience with New Public Management (NPM). Under the Kim Dae-Jung administration (1998-2002), Korea experimented with drastic system change that was almost unprecedented in its range and depth (Kim 2005). However, the Roh Moo-Hyun administration (20032007) reversed many of its predecessor's policies, which had been largely driven by an NPM rationale.

Did the Korean reforms and their aftermath constitute a policy fashion? This question is especially legitimate in view of the changing size of the Korean government. During the Kim Dae-Jung administration, the total civil service workforce was

* Hyeong-Wook Boo is an associate research fellow at the Korea Institute for Defense Analyses (KIDA). He received his PhD from Virginia Tech and his MA and BS from Seoul National University. He joined KIDA in 1996 and has participated in more than 30 research projects since then. His research interests include military capabilities evaluation, crisis management, and strategic planning. Dr. Boo is also interested in organizational issues such as interagency coordination and network management. E-mail: soyareen@gmail.com.

Manuscript received October 7, 2009; out for review November 1, 2009; review completed March 8, 2010; accepted March 23, 2010.

The Korean Journal of Policy Studies, Vol. 25, No. 1, 19-33 (2010)

(C) 2010 by the GSPA, Seoul National University 
reduced from 933,899 to 889,993 , while the Roh administration increased the number again; it reached 950,986 in 2007 (Park 2005; Lee 2007). While there were many examples of drastic change during these periods (for example, expenditures and organizational growth), the number of civil servants is one accepted measure of change.

Having observed fashion-like phenomena in the adoption of NPM or other policy packages in Korea and European countries, one may see that there is a need for theoretical discussion of the policy fashion concept. This study attempts to apply the concept to the experience of NPM-driven reform in Korea while clarifying the concept itself and exploring its usefulness. The final section discusses the result of this application and its theoretical implications.

\section{THE POLICY FASHION CONCEPT}

\section{Application to European Countries}

Harrison (2004) developed the concept of policy fashion by applying Abrahamson and Fairchild's (1999) management fashion concept to the public sector. Abrahamson and Fairchild $(1999,709)$ described management fashion as the "relatively transitory collective beliefs disseminated by the discourse of management-knowledge entrepreneurs." They pointed to consistent reports of short-lived, bell-shaped popularity curves for specific management techniques and argued that, in the collective learning process, superstitious learning dominates the adoption of a new fashion. That is, when an organization faces a crisis or recognizes a performance gap, this causes anxiety, and certain sociopsychological forces mediate the adoption of a management technique. They argued the management fashion concept is critical for organizational research because most organizations are in a more-or-less transitory status, and that neoinstitutionalists should focus on these fad-like phenomena if they do not want to be criticized for unduly overemphasizing one aspect of organizational phenomena (Abrahamson and Fairchild 1999).

Harrison borrowed this concept when he studied the health care policies of the Netherlands, Sweden, and the United Kingdom, tailoring it for application to characteristics unique to the public sector, such as agenda setting and coalition building in the implementation of fashionable policies. In so doing, he tried to redefine the fashion concept for the public sector as a relatively transitory collective belief. Harrison (2004, 194) used the term fashion for public policy in a "non-pejorative sense to describe shifts in support for policies that reflect an underlying process of fashion-setting, formulation, and implementation."

Harrison reported that there was short-lived political support for reform programs 
driven by market principles, and that some programs were not fully implemented because support from politicians and the electorate was too short-lived. In this respect, he pointed out that policy implementation might be marred by the rapid fluctuations in political support for the polices. He also suggested that many bureaucrats who are in charge of implementation might show cynicism about a policy after experiencing a "fashion" cycle in the public policy domain.

Even though Harrison warned about the possible disadvantages of fashion-like policy formation, he admitted that such practices are quite prevalent and seem to be unavoidable in contemporary society (Harrison 2004). With the current pace of globalization, new ideas and techniques are rapidly spreading throughout the world. Also, increasing numbers of citizens recognize themselves as consumers of government services and have become more conscious of other countries' best practices. Therefore, there is good reason for policy makers to continue searching for new policy issues and new solutions to them.

\section{Comparison with Other Concepts}

Other scholars have studied the phenomenon that Harrison labeled policy fashion. According to Dolowitz and Marsh $(2000,5)$, many studies have dealt with "a similar process in which knowledge about policies, administrative arrangements, institutions and ideas in one political setting (past or present) is used in the development of policies, administrative arrangements, institutions and ideas in another political setting." Because scholars use so many different terms-including policy diffusion, policy transfer, policy convergence, and lesson-drawing-there is a potential for confusion and a need to examine the difference between policy fashion and other related concepts.

The term "policy transfer" is prevalent among scholars and is used as overarching concept. Dolowitz and March (2000) used the term "lesson-drawing" to refer to a voluntarily and rationally chosen transfer. Banks, Disney, Duncan and Van Reenen (2005) used the concept of "policy convergence" to describe the result of policy transfer. Radaelli (2000) commented that the term "policy diffusion" was originally used to describe the migration of policy choices from federal government to state governments. Yet another concept, "isomorphism," developed within organizational theory, focuses on the convergent phenomena in structural and functional arrangements (Lynn 1998, 234). According to Radaelli (2000), many organizations and governments use mimetic isomorphism ${ }^{1}$ in their structures and activity patterns in order to secure their legitimacy. Table 1 compares these concepts.

1. Mimetic isomorphism refers to phenomena that an organization imitates other organizations' structural or functional choices hoping that they would be beneficial to the organization, too. 
Table 1. Comparison of Concepts

\begin{tabular}{llll}
\hline Concept & Highlights of the concept & Level of analysis & Focus \\
\hline Policy fashion & $\begin{array}{l}\text { Fluctuation of support for imported or } \\
\text { transferred policy agendas }\end{array}$ & $\begin{array}{l}\text { International } \\
\text { and domestic }\end{array}$ & $\begin{array}{l}\text { Overall policy } \\
\text { process }\end{array}$ \\
\hline Lesson drawing & $\begin{array}{l}\text { Voluntarily and rationally chosen policy } \\
\text { transfer }\end{array}$ & International & Policy formation \\
\hline Policy transfer & $\begin{array}{l}\text { Adoption of policies from foreign } \\
\text { countries with similar experiences }\end{array}$ & International & Policy formation \\
\hline Policy convergence & $\begin{array}{l}\text { Similar to policy transfer concept; } \\
\text { sometimes used to refer to the results } \\
\text { of policy transfer }\end{array}$ & International & Policy formation \\
\hline Policy diffusion & $\begin{array}{l}\text { Domestic policy migration from federal } \\
\text { to state level }\end{array}$ & Domestic & Policy formation \\
\hline Isomorphism & $\begin{array}{l}\text { Convergence in structural or functional } \\
\text { arrangements among organizations }\end{array}$ & Organizational & N/A \\
\hline
\end{tabular}

At first glance, policy fashion may seem to be a new term for existing phenomena, because it refers to a kind of policy transfer driven by the bandwagon effect. However, the policy fashion concept is unique in two ways: (1) it focuses on the fluctuation of support for an imported or transferred policy agenda, and (2) it deals with the implementation process as well as the policy formation process. Harrison (2004) used this term to refer to a series of policy processes: agenda setting (or fashion setting), policy formation, policy implementation, and policy change (or policy decline and the search for alternatives).

\section{POLICY FASHION IN KOREA FROM 1998 TO 2007}

\section{Overview}

This case study compares two time periods: 1998-2002, when drastic system changes took place under the Kim Dae-Jung administration, and 2003-2007, when reaction against the previous reform package occurred during the Rho Moo-Hyun administration. As in the European cases that Harrison studied, Korea experienced a rapid rise and fall of political support for the NPM-driven policy packages, largely influenced by policy entrepreneurs, congruent with Harrison's emphasis on the role of policy entrepreneurs, who he argued are a major source of fashion setting.

There may be several answers to the question of which specific policy fashion was 
set in Korea. According to Cheung (2005), two different paradigms have been recognized as reform models for Asian countries in the last decade: the NPM model and the "good governance" model. The Korean government can be said to have adopted both reform models. Faced with the Asian financial crisis of 1997, the Kim administration broke with past practices and audaciously implemented the entire NPM reform model. Later, the Rho administration adopted the good governance model. As a result, political support for "small government," a key tenet of the Kim administration, was somewhat weakened. During the Rho administration, politicians openly asserted that certain government functions, for example the welfare administration apparatus, should be expanded, and the president supported this approach.

Thus, one of the most drastic NPM reform cases in the world lasted five years. In fact, writers argue that the Kim administration's bold attempts to implement NPM reform lasted only for three years, because President Kim Dae-Jung experienced strong resistance from the bureaucracy during the last two years of his presidency. The Rho administration quickly revised those reform programs, even though Rho had promised during his campaign that he would sustain the policies of the Kim administration. As an example of the drastic change brought about by the reforms, figure 1 displays the changes in the number of civil servants during three consecutive regimes (Kim 2000; Park 2005; Lee 2005; Lee 2007).

Figure 1. Changes in the Number of Civil Servants 1993-2007*

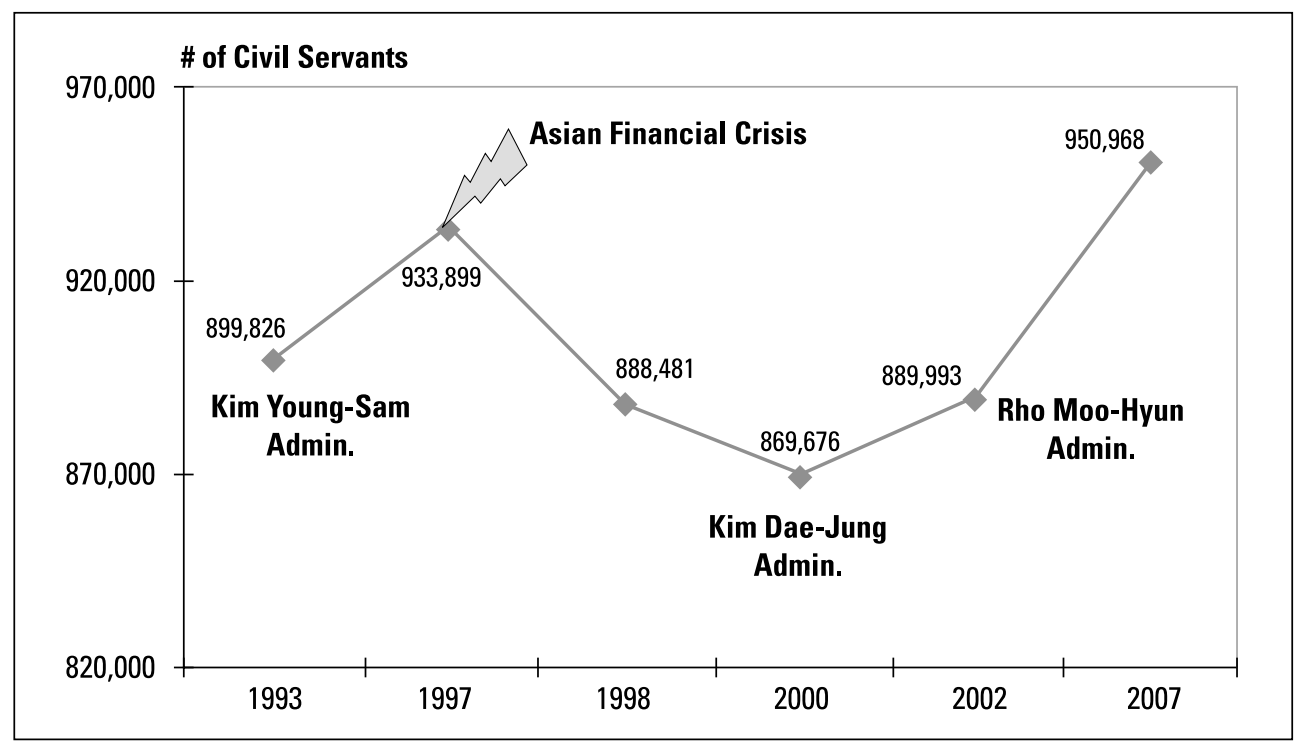

* Year 1997and 2000 is added to show the drastic change in the number of civil servants. 


\section{Fashion Setting in 1998}

The years 1993-1997 could be considered the latent period of NPM reform. In the early 1990s, Korean scholars began discussing the possibility of adopting NPM as a government reform model. After ending 30 years of military-controlled authoritarian government, president-elect Kim Young-Sam proclaimed that continuing the democratization process, promoting globalization, and restructuring in favor of small government would be the guiding principles of his administration.

These metapolicy choices were largely influenced by academia. In the early 1990s, many scholars, no doubt influenced by the worldwide spread of neoliberalism and globalization, showed an interest in reducing government size in concert with many Western countries' reform agendas. The general public in Korea became aware of the trend toward government reinvention in Western countries. Furthermore, many Korean scholars and high officials became familiar with NPM-driven policy proposals. In 1996, there was a government-initiated study, involving a number of scholars and government officials, of reform efforts in Canada, New Zealand, the United Kingdom, and the United States (Ministry of Government Administration 1997). This period can be seen as the learning process for the NPM reform model, and one can argue that the foundation for instituting new NPM policy packages was laid at this time.

From 1998 to 2000, economic crisis can be seen as having led to fashion setting. The Asian financial crisis of 1997 had a devastating impact on the Korean economy. It was the worst recession since the Korean War of 1950, and it triggered many socioeconomic problems such as huge layoffs, record-high unemployment, and record-low GDP growth (-5.8 percent in 1998). Many Korean people regarded this financial crisis as a national catastrophe as devastating as the war itself had been.

President Kim Dae-Jung took office at the beginning of the financial crisis and instituted NPM-driven reform policies, which received wide public support. People perceived the causes of the financial crisis to be the state-led economy and inefficient government bureaucracy, and thus believed that the reform needed to address the entire system - including the financial system, the business sector, labor, and the public sector. Even though the effect of the reform was greatest for the financial and labor sectors, the depth and breadth of public sector reform was also substantial. The focus of the public sector reform included downsizing of the government bureaucracy and a comprehensive privatization plan (Kim 2000). During the Kim Dae-Jung administration, the public work force was cut by 140,300 personnel, and many state-owned enterprises were privatized in a short period of time (Kim and Park 2005).

How can this situation be understood using the policy fashion perspective? There are several possible explanations, but a strong argument can be made that policy entre- 
preneurs were a critical force behind this NPM-driven reform. In recognizing fashionsetters or policy entrepreneurs, we first need to examine the influence of President Kim Dae-Jung as a fashion-setter. The differences between policy choices made by Korea and Japan in response to the 1997 financial crisis may shed light on this issue. Kim (2005) reported that Korean government actively implemented NPM-driven policies in order to overcome economic hardship, whereas the Japanese government changed its policies more gradually. He argued that Korea's wholesale adoption of NPM was made possible by the fact that a Korean president is more powerful than a Japanese prime minister. Also, Korea faced more serious problems than Japan. Moreover, the entrepreneurial role of President Kim is highlighted by his wholesale adoption of reform. He increased the authority of the Korean presidency by making use of his charisma and leadership capacity. Indeed, if it were not for his powerful leadership, coupled with the widespread sense of crisis, the reforms would probably not have gained broad public support during the initial stages.

The Korean government adopted the more radical Westminster countries' NPM reform package rather than the U.S. model. ${ }^{2}$ This choice may be explained by the preferences of senior government officials who were recruited by President Kim-for example, Jin Nyum, the first minister of the newly established Planning and Budget Commission (PBC), and Lee Kye-Sik, a former researcher in the Korea Development Institute, later the first director of the Government Reform Office within the PBC. ${ }^{3}$ Jin and Lee openly lobbied for Korea's adoption of government reform in the spirit of the New Zealand and British models (Lim 1998). Thus, one can argue that President Kim set the overall policy orientation and policy entrepreneurs (for example, Jin and Lee) implemented it. While those policy entrepreneurs were selecting specific policy alternatives, they imposed their policy preferences, making Korean government reform similar to that of the Westminster countries, especially New Zealand. Later, Professor Sung-Sig Youn, a member of the Presidential Advisory Committee under the Kim administration, argued that there was a fallacy 4 among scholars and practitioners regarding the New Zealand model (Youn 2002).

Considering all these facts, one can argue that the policy choices of the Kim

2. The Westminster countries adhered more closely to market principles in reforming their governments, and the range of the reform was deeper and broader than that of the United States.

3. The Government Reform Office played a major role in government restructuring and reorganization. Personnel from outside of the government were appointed to major posts within this office, which was an unusual way of recruiting (Kim 2001).

4. That is, scholars had a fallacy that the New Zealand model would be the best fit for Korea and it would address problems brought by the financial crisis. 
administration demonstrated fashionable characteristics as follows:

- NPM-led government reform was an international trend at that time.

- Even though there were external pressures for reform, especially from the International Monetary Fund, the Kim administration's choices circumvented the Fund's recommendations with a full-scale adoption of NPM-based reform packages.

- Political support from the general public, the political parties, and the government bureaucracy was considerable because people saw themselves in a national catastrophe. Some citizens wanted even more drastic changes.

\section{Reform Fatigue and Resistance to NPM Reform}

The Kim administration's bold reforms acquired strong political support from the general public, the opposition, and the mass media (Mo 2000). Indeed, the entire country united and cooperated with the leadership in order to overcome its economic malaise. People recognized that there were no alternatives. Mo (2000) described it as a "honeymoon period" for the Kim administration. Nevertheless, complaints, resistance, and reform fatigue eventually became pervasive.

The hastily improvised and imported reform agenda caused many problems. For example, in describing the public sector restructuring, Chung (2000) used the metaphor of putting a gun to the heads of bureaucrats to follow the mandates. In the name of sharing the burden with the private sector, which was undergoing painful restructuring, the public sector was forced to set layoff quotas that were imposed by the $\mathrm{PBC}$ in an across-the-board manner.

Another cause of resistance to the reform program was the exclusion of public administration scholars and managers from the formation of the reform policies. Many private consulting companies, including AT Kearney and Anderson Consulting, reviewed the government's performance and structural problems (Kim 2000). Their participation in government reform was unprecedented in Korea. As a result, many public administration scholars argued that the Kim administration overlooked the expertise that public administration practitioners and scholars could have brought to the reform process.

Scholars like Ahn Byung-Young warned that the Kim administration's reliance on neoliberalism could cause many problems in Korean society (Ahn 1999). He argued that because Korea was on a different state development path, Anglo-American concepts of government should not be applied to the Korean government. Meanwhile, many public servants criticized the reform on the ground that it was implemented autocratically and without consensus. Scholars and practitioners also argued that con- 
fusion, favoritism, and power politics were widespread in implementing the reform.

In this regard, political support for the Kim administration's reform agenda lasted about three years at most. Indeed, support from academia and the government bureaucracy lasted less than one year. In May 1999, when follow-up reform plans were being prepared by private consulting firms, practitioners began to show their antipathy to the reform policy, for example by submitting articles to the mass media. In 2000, scholarly articles criticizing the NPM reform peppered academic journals such as the Korean Review of Public Administration and the International Review of Public Administration. Finally, lacking support from opinion leaders and the general public, the Kim administration's reform efforts ended up with the minimal result of structural adjustment and some reduction in the number of public servants.

When it came to rejecting or resisting the reform, Korean society as a whole demonstrated rational tendency. Scholars attempted to show why the Anglo-American reform models could not fit Korean society. Practitioners and the general public began to discuss the possible loss and harm to Korean democracy and public administration caused by the NPM-driven reform. Whereas the general direction of the reform agenda was set within the first three months of the Kim administration, these debates and concerns lasted until the end of that administration. Arguably, this is typical of the fashion-setting process, in which the general public, policy makers, and the media demonstrate rationality in rethinking the fashion. As mentioned earlier, this tendency is the polar opposite of fashion setting, in which rationality gives way to more faddish models_-for example, mimetic motives.

\section{Fashion Setting in 2002: Thermidorian Reaction?}

President Rho was elected with wide support from the relatively young generation that triggered and led the democratization process in Korea. As a favorite of that generation, he argued that participation and discussion should be among the leading values of his administration. In this context, he identified his administration as promoting participatory government. Applying this value to administrative reform, the Rho administration officially announced a rethinking of the small-government agenda (Nam 2004). Thus, President Rho, who was regarded as an ardent supporter of President Kim, said that he would rethink the principle most highly valued by his predecessor.

President Rho took office when public servants' resistance to the NPM-driven reform was at a peak and the many adverse effects of the reform were becoming unbearable. For example, there had been incessant criticisms from academia about imposing NPM on the Korean government. Many public administration scholars remained critical of the Kim administration's reform process. Confronted by criticism and the stalling of the 
NPM-driven reform, the Rho administration needed to change direction quickly. Public administration scholars who had been ardent critics of NPM-driven reform during the Kim administration participated from the beginning in preparing the Rho administration's administrative reform agenda. Their influence had been growing, and that was a real turnaround from the situation under the Kim administration. ${ }^{5}$

With respect to the theoretical foundation of the new policy fashion, many scholars had sought alternatives to the NPM reform model. While good governance or democratic governance was considered a guiding principle, many argued that B. Guy Peters' "participatory state" model might be the best theoretical framework for reform (Nam 2004). ${ }^{6}$ Since the participatory state model emphasizes that public servants should be regarded as the subject of the reform rather than the object of it, it delves into the notion of empowerment of public servants as well as citizens. In this regard, scholars found the participatory state model a viable alternative for reform. The characteristics of this model and the good-governance model seemed to appeal to public servants who were agonized by NPM-driven restructuring.

From the perspective of proponents of small government and results-oriented public administration, the Rho administration could not be regarded as a success. To some, it was simply a reaction to the NPM model—because, for example, the number of public servants was growing and had reached its highest point. Several privatization plans for state-owned public enterprises were postponed. Moreover, President Rho said openly that he was not concerned about bigger government as long as the government worked properly. These were very frustrating developments for the NPM reformers, and criticisms of the government's growing size soared among the general public.

\section{THEORETICAL IMPLICATIONS}

The fashion concept is attractive for describing social phenomena. Korea's recent experience of administrative reform agenda setting seems to be well suited to this concept, but it is still questionable whether it can be applied widely. The appeal of policy

5. Professor Ahn Byung-Young became the deputy prime minister, and Professors Kim Byung-Joon and Youn Sung-Sig took the office of chairman of the Presidential Committee on Governmental Innovation and Decentralization in turns.

6. According to Nam (2004), the terms "good governance model" and "participatory state model" can be used interchangeably. B. Guy Peters' book The Future of Governing: Four Emerging Models (1996) was translated into Korean in 1998 when the NPM-driven reform model was sweeping the nation. 
phenomena may have time- and place-specific characteristics. For example, administrative reforms in Japan and Korea in response to the Asian financial crisis differed, with Japan continuing steady yet modest reform programs while the Korean government attempted to implement drastic reforms during the first phase of the crisis but could not sustain them when political support diminished (Kim 2005).

This raises the question of whether the policy fashion concept fits the Korean situation by accident or whether Korea's culture makes it especially susceptible to fads. Henderson (1968) pointed out the sweeping nature of Korean politics. In his seminal book Korea: The Politics of the Vortex, he said that if one political elite acquired power, other voices in the society would be overwhelmed by its ideology. It is important to carefully take into account the characteristics of a society when applying the fashion concept, since its applicability may be limited in certain political contexts.

The following observations could inform theoretical arguments about the Korean government's experiences during the recent reform process:

-Definition of the situation: A leader's role in framing urgent policy issues is critically important, as noted by several scholars, including John Kingdon (1997). The president often defines the situation and sets the general orientation of policies. Presidents Kim and Roh played major roles in defining situations and mobilizing political support for specific policy packages. ${ }^{7}$

- Accumulated knowledge: The bureaucracy's role was crucial in adopting and revising the NPM-driven policy package, as posited in the research of many scholars. It absorbed international trends and academic arguments about best practice into its institutional memory and used them when needed. From 1998, the role of the government bureaucracy was to give concrete form to the general policy orientation imposed by the president. In so doing, policy entrepreneurs in the bureaucracy tried to reflect their own policy preferences, such as NPM and good governance, in proposed policy alternatives.

- Knowledge created by scholars: The most salient point about fashion setting in Korea has been the active participation and the growing influence of scholars. In providing the rationale for discarding parts of the NPM agenda, the influence of academia was more powerful than has usually been observed in studies of policy formulation in Western countries. As for the adoption of the good governance model, some scholars were able to directly influence the framing of the Rho administration's policy orientation. Scholars were also in the vanguard in importing other countries' experiences and best practices in public

7. President Kim perceived NPM as the best way to overcome the crisis. President Rho thought that the stalemate regarding NPM-driven reform and its adverse effects could be resolved using the participatory state model. Both presidents were quite successful in mobilizing political support in the early stage of their initiatives. 
administration. Their arguments strongly influenced issue perception, policy formulation, and policy change.

- Social needs and mimetic processes: Newly emerging policy issues, social needs, and the financial crisis inspired a sense of emergency, and this triggered a mimetic process of policy adoption by the leadership, academia, and the government bureaucracy. Under the Kim, Dae-Jung administration, the sense of urgency triggered the wholesale adoption of NPM-driven reform. During the Rho administration, growing antipathy regarding adverse effects of NPM reform made policy entrepreneurs consider the adoption of participatory state model in an effort to quell resistance. In contrast, reform initiatives under Kim, Young-Sam administrations had wide acceptance within the government bureaucracy but failed to acquire political support since there was no sense of urgency.

Figure 2 applies the policy fashion concept to the Korean experience and depicts the influential fashion-setting factors in Korea's policy process, revealing four important fashion-setting characteristics or mechanisms.

Figure 2. Policy Fashion Dynamics: The Recent Experience of Korea

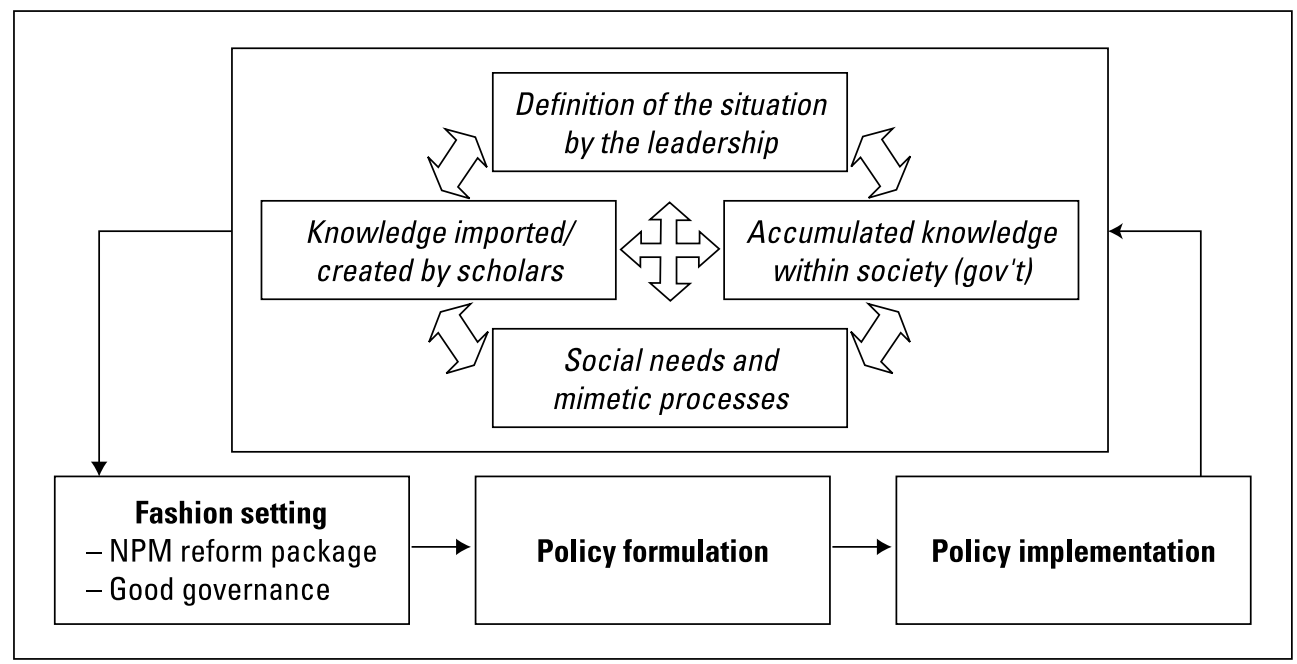

There are at least two possible criticisms regarding this diagram and the relevance of the policy fashion perspective for the Korean government's recent reform experiences. First, one may argue that the identified fashion-setting factors in Korea are not different from the policy environment or demand and support for policy. However, as mentioned earlier, the focus of the policy fashion perspective lies in fashion-like phe- 
nomena in policy formulation and the superstitious learning process as opposed to rational choice. Moreover, the policy fashion perspective eventually warns policy makers and their implementers of the possibility of waste of resources resulting from fashion-like adoption of certain policy measures. In this regard, the application of the policy fashion concept to recent Korean reform cases provides a practical lesson as well as an attractive explanation.

Second, one may criticize the policy fashion perspective for incorporating the "stage heuristic" approach to the policy process, which has been widely criticized. ${ }^{8}$ However, while it does maintain the stage heuristic approach, the policy fashion perspective also tries to incorporate recent theoretical advances in policy studies. Harrison's emphasis on the role of the policy entrepreneur and superstitious learning in the policy process seems to be the result of its being influenced by Kingdon's(1997) "multiple streams" model and Baumgartner and Jones'(1993) "punctuated equilibrium” model. 9

Thus, the policy fashion perspective provides a new approach that can provide a bridge between the relatively old stage heuristic approach and newly emerging theoretical frameworks. In this regard, the policy fashion perspective, as a complementary perspective to the stages heuristic, merits further research.

\section{REFERENCES}

Abrahamson, E., and G. Fairchild. 1999. Management fashion: Lifecycles, triggers, and collective learning process. Administrative Science Quarterly 44(4): 708-40.

8. Jenkin-Smith and Sabatier (1993) argued that the stage heuristic (1) is not a causal model and does not allow for prediction; (2) does not provide a basis for empirical hypothesis testing; (3) suffers from descriptive inaccuracy; (4) has a legalistic, top-down focus; (5) uses a temporal unit of analysis, the single policy cycle; and (6) fails to integrate policy analysis and policy-oriented learning throughout the policy process.

9. The punctuated equilibrium framework (PEF), a concept taken from evolutionary science, seeks to explain why the policy process is characterized by stability at some times and dramatic change at others. The PEF has its foundations in bounded rationality and institutionalism. Because of bounded rationality, policy issues can be handled only serially or a few issues at a time, forcing the macropolitical institutions (legislature and president) to let the policy subsystem deal with most issues. Institutions create policy subsystems that can turn into policy monopolies. A successful policy monopoly results in negative feedback, which hinders change. However, if environmental pressures are sufficient, they may lead to a massive intervention from macropolitical institutions, which may result in radical changes in public policies (True. 2000). 
Ahn, B.-Y. 1999. Kim Dae Jung jungbuga bbazilsu inun sinjayujuii hamjung [The possible pitfall of neoliberalism that the Kim administration might be falling into]. Shindonga, April. http://www.donga.com/docs/magazine/new_donga/9904/ nd99040140.html.

Banks, J., R. Disney, A. Duncan, and J. Van Reenen. 2005. The internationalization of public welfare policy. The Economic Journal 115: 62-81.

Barzelay, M. 2001. The new public management: Improving research and policy dialogue. Berkeley, CA: University of California Press.

Baumgartner, F. R. and Jones, B. D. 1993. Agendas and instability in American politics. Chicago and London; University of Chicago Press.

Cheung, A. B. L. 2005. The politics of administrative reforms in Asia: Paradigms and legacies, paths and diversities. Governance: An International Journal of Policy and Administration 18(2): 257-82.

Choi, D. 2001. A radical approach to regulatory reform in Korea. Paper presented at the 2001 conference of the American Society for Public Administration at Rutgers University, Newark, NJ.

Chung, C.-K. 2000. Haengjunghaki Saeroun Ihae [The new public administration]. Seoul: DaeMyung Publishing Co.

Dolowitz, D. P. and D. Marsh. 2000. Learning from abroad: The role of policy transfer in contemporary policy-making. Governance: An International Journal of Policy and Administration 13(1): 5-24.

Harrison, M. I. 2004. Implementing change in health systems: Market reforms in the United Kingdom, Sweden and the Netherlands. London: Sage Publications.

Henderson, G. 1968. Korea: The politics of the vortex. Cambridge, MA: Harvard University Press.

Kim, B.-S., and S.-H. Park. 2005. Hankuki Jungbu Gaehyuk: Sunggwa, Munjae Kuriko Gwajae [History of government reform in Korea: The good, the bad, and the ugly]. Seoul: Korean Association for Public Administration Summer Symposium Series.

Kim, J.-H. 2001. The quality of public expenditure: Challenges and solutions of resultfocused management system in the Korean public sector. Paris: Organisation for Economic Co-operation and Development, http://www.oecd.org/dataoecd/3/57/ 2497102.pdf.

Kim, S.-B. 2000. Reform efforts toward new public management in Korea. Paper presented at the IIAS/Japan Joint Panel on Public Administration, Bologna, Italy.

Kim, W. 2005. Policy reform in Japan and South Korea (1997-2002). International Review of Public Administration 9(2): 39-53.

Kingdon, J. 1997. Agendas, alternatives, and public policies. New York: Longman 
Lee, S.-H. 2007. Lee Myung Bak, gongmuwon su dongkyul haketda[Lee, MyungBak, will not increase the number of civil servants workforce. Dongailbo. http://www.donga.com/fbin/output?n=200711170108.

Lee, S.-W. 2005. Gongmuwon sutja ryukdae choida[The number of civil servants, record high]. DongAIlbo. Chosunilbo. http://www.chosun.com/politics/news/ 200509/200509280371.html.

Lim, K.-J. 1998, September. DJ Jungbu ryukkaewol[Six months of the Kim Dae-Jung administration]. Shindonga, http://www.dongailbo.co.kr/docs/magazine/new_ donga/9809/nd98090043.html.

Lynn, L. E. 1998. The new public management: How to transform a theme into a legacy. Public Administration Review 58(3): 231-37.

Ministry of Government Administration. 1997. Shin jungbu hyukshinron [New government reform: OECD nations' case]. Seoul: DongMyungSa.

Mo, J.-R. 2000. The politics of economic reform: South Korea. Background Studies Prepared for the Bangkok Meeting. Washington D.C.: Carnegie Endowment for International Peace.

Nam, K.-K. 2004. Minjujuk governancewa chamyeojungbui jungbu hyukshin [Democratic governance and government reform of the participatory government]. The Administration Focus, March-April.

Park, S.-K. 2005. Kim Dae Jung jungbuwa Rho Moo Hyun jungbui haengjung gaehyuk bikyo [A comparison of administrative reform between the Kim Dae-Jung administration and the Rho Moo-Hyun administration]. Seoul: The Korean Association for Public Administration Summer Symposium Series.

Peters, B. Guy. 1996. The future of governing: Four emerging models. Lawrence: University Press of Kansas.

Radaelli, C. M. 2000. Policy transfer in the European Union: Institutional isomorphism as a source of legitimacy. Governance: An International Journal of Policy and Administration 13(1): 25-43.

Sabatier, P. A. and Jenkins-Smith, H. C. 1993. Policy change and learning: an advocacy coalition approach. San Francisco: Westview Press.

True, J. L. 2000. Avalanches and incremetalism. American Review of Public Administration 30(1): 3-18.

Youn, S.-S. 2002. The vision and strategy of government reform. Seoul: Open Books. 